surface-active pulmonary lipoprotein. Amer. Rev. Resp. Dis., 102: $285(1970)$

26. Scarpelli, E. M., Condorelli, S., Colacicco, G., and Cosmi, E. V.: Lamb fetal pulmonary fluid. II. Fate of phosphatidylcholine. Pediat. Res. 9: 195 (1975).

27. Schneeberger-Keely, E. E., and Karnovsky, M. J.: The influence of intravascular fluid volume on the permeability of newborn and adult mouse lungs to ultrastructural protein tracers. J. Cell Biol., 49: 319 (1971).

28. Setnikar, I., Agostoni, E., and Taglietti, A.: The fetal lung, a source of amniotic fluid. Proc. Soc. Exp. Biol. Med., 101: 842 (1959).

29. Von Neergaard, K.: Neue auffassungen über einen grundbegriff der atemmechanik. Die retraktionskraft der lunge, abhängig von der oberflächenspannung in den alveolen. Z. Ges. Med., 66: 373 (1929).

30. Air Shields, Hatboro, Pa.

31. Albumotope (radio-iodinated $\left({ }^{1}{ }^{31}\right.$ I)human serum albumin), 0.05 $\mathrm{mCi} / \mathrm{mg}$; Travelon Lab., Inc., Costa Mesa, Calif.

32. $\left[U^{14} \mathrm{C}\right]$ Phosphatidylcholine complexed with $5 \%$ protein was injected simultaneously with RISA into FPF of fetuses 1,2 , and 3 (see Reference 25).

33. Automatic Gamma counter system, model 1085, Nuclear Chicago, Des Plaines, Ill.

34. Physiograph Six-B, Narco-Bio Systems, Houston, Tex.

Copyright (c) 1975 International Pediatric Research Foundation, Inc.
35. $\mathrm{P}=\frac{(2)(\gamma)}{(\mathrm{r})}(10)$, where $\gamma=$ surface tension in dynes per centimeter; $\mathrm{P}=$ retractive pressure due to $\gamma$ (assumed to be $1.5-2.0 \mathrm{~cm}$ $\mathrm{H}_{2} \mathrm{O}$ ); $\mathrm{r}=$ mean alveolar radius (assumed to be $50 \mu \mathrm{m}$ ). Substituting in equation gives $\gamma=3.75-5.0$ dynes $/ \mathrm{cm}$.

36. We have also observed a transient state which begins at the onset of breathing and in which foam is present in the airways and presumably also in the periphery of the lung. Mixture of air with FPF would expectedly produce foam. Thus the transitional state between liquid-lung and air-lung is the stage of the "foam-lung." 37 . We have been able to produce regular breathing movements in the fetus consistently by stimulation of the sciatic nerve. This is the topic of a separate study in our laboratory.

38. This research was supported by Grants from the National Heart and Lung Institute, National Institutes of Health (HL16137); New York Heart Association grant-in-aid; and United States-Italy Cooperative Science Program (C. N. R., Rome, No. 73.00681.65.

39. Dr. Scarpelli is a recipient of a Career Development Award from the National Heart and Lung Institute of the National Institutes of Health.

40. Requests for reprints should be addressed to: E. M. Scarpelli, M.D., Department of Pediatrics, Albert Einstein College of Medicine, 1300 Morris Park Ave., Bronx, N.Y. 10461 (USA).

41. Accepted for publication January 2, 1975.

Printed in U.S.A.

Pediat. Res. 9: 195-201 (19\%5)

Alveoli lung

fetal pulmonary fluid phosphatidylcholine clearance fetus

\title{
Lamb Fetal Pulmonary Fluid. II. Fate of Phosphatidylcholine
}

\author{
EMILE M. SCARPELLI, ${ }^{(39)}$ SALVATORE CONDORELLI, GIUSEPPE COLACICCO, AND \\ ERMELANDO V. COSMI \\ WITH THE TECHNICAL ASSISTANCE OF FRANKLIN A. TAYLOR, JR., AND MARY LOUISE SKOVRON
}

Pulmonary Division, Department of Pediatrics, and Department of Anesthesiology, Albert Einstein College of Medicine, Bronx, New York, USA, and the University of Rome, Rome, Italy

\section{Extract}

Using the radio-iodinated human serum albumin $\left(\left[\begin{array}{lll}1 & 3 & 1\end{array}\right]\right.$. RISA) dilution method to measure lamb fetal pulmonary fluid (FPF) volume, we followed the disappearance of proteincomplexed, ${ }^{14} \mathrm{C}$-labeled phosphatidylcholine $\left(\left[{ }^{14} \mathrm{C}\right] \mathrm{PC}\right)$ during the first $90 \mathrm{~min}$ after its injection into FPF. The FPF samples were analyzed for total lipid ${ }^{14} \mathrm{C}$ activity and for distribution of ${ }^{14} \mathrm{C}$ in PC, other phospholipids (PL), fatty acids (FA), and neutral lipids (NL). For most sampling periods ascending aortic (AAo) and right atrial (RA) blood samples were obtained simultaneously with FPF and serum was analyzed for total lipid ${ }^{14} \mathrm{C}$ activity and for distribution of ${ }^{14} \mathrm{C}$ in total PL, FA, and NL. These studies indicate that (1) $\mathrm{PC}$ is cleared rapidly from FPF with an estimated half-time of 15-57 min; (2) FPF-PC may be metabolized to lyso-PC and FA within the fluid itself; and (3) FA derived from FPF-PC enter the pulmonary circulation, thus establishing a pulmonary arteriovenous FA gradient. The possible sites at which PC may be cleared from FPF are considered.

\section{Speculation}

The novel possibility is suggested that FPF contains annronriate enzvmes (nhosnholinase(s)) for deacvlation of PC and also that PC-degradative enzymes are active at the surface of the alveolar epithelial cells. By comparison with results of others regarding the half-life of PC in the air-lung, it appears that PC clearance outside the cell (i.e., after secretion) occupies a relatively short period in the turnover of the molecule. Since the products of PC degradation appear in arterial blood as FA primarily, we may consider FPF as a possible source of serum $F A$.

Phospholipids, including surface-active phospholipids, are synthesized by the fetal lung and secreted into the FPF (19). With FPF they are expelled periodically from the lung of the lamb fetus and are swallowed (1). Whether or not they also enter the amniotic fluid compartment and add in a significant way to its phospholipid content is a moot question which, with regard to the lamb fetus, has received a negative answer (5). The metabolic fate of FPF phospholipids, of which phosphatidylcholine (PC) is the major component $(2,19)$, is not known. Whereas pulmonary PC of adult animals has been shown to have a half-life of about $12-14 \mathrm{hr}(27,28)$, the pathway(s) by which PC is degraded or removed from the alveoli have not been determined. 
In the present studies, $\left[{ }^{14} \mathrm{C}\right] \mathrm{PC}$ complexed with protein was injected into FPF of lamb fetuses in utero. Simultaneous determinations of FPF volume and volume change by the

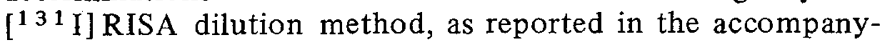
ing paper (25), permitted sequential evaluation of PC clearance in FPF. In addition, we were able to follow incorporation of the ${ }^{14} \mathrm{C}$ label into other lipids of FPF and its presence in lipids of the blood. These studies show that the half-time of FPF-PC is short and that fatty acids derived from FPF-PC are recovered in the circulation. Possible routes of PC clearance are discussed.

\section{METHODS}

Three pregnant ewes $(>135$ days gestation) were anesthetized with $\mathrm{Na}$ pentobarbital, $15 \mathrm{mg} / \mathrm{kg}$, tracheostomized, and placed on a ventilator (30). Anesthesia was maintained with $\mathrm{N}_{2} \mathrm{O}: \mathrm{O}_{2} 75: 25$ throughout the experiment. Arterial blood was maintained at a $\mathrm{P}_{\mathrm{O}_{2}}$ of $85-110 \mathrm{~mm} \mathrm{Hg}, \mathrm{P}_{\mathrm{CO}_{2}}$ of $35-45$ $\mathrm{mm} \mathrm{Hg}$, and $\mathrm{pH}$ of $7.38-7.42$.

\section{PREPARATION OF FETUS}

The fetuses, three (fetuses 1, 2, and 3) of which were subjects of the experiments reported in the accompanying paper (25), were prepared as described in that report. The fetal trachea was cannulated and catheters were advanced to the ascending aorta (AAo) and right atrium (RA). Fetuses 1 and 2 were twins and fetuses 3 and 4 were singletons.

\section{ISOTOPE DILUTION}

Human [ $\left[\begin{array}{lll}{ }^{3} & 1 & \text { I }\end{array}\right]$ RISA (hereafter written RISA), $1-2 \mu \mathrm{Ci}$, was mixed with $2.5 \mu \mathrm{Ci}\left[{ }^{14} \mathrm{C}\right] \mathrm{PC}$ complexed with $5 \%$ protein $(31)$ in $1.0 \mathrm{ml} 0.15 \mathrm{M} \mathrm{NaCl}$ and injected into the tracheal cannula. Thus about $50 \mathrm{mg}$ protein and $1 \mu \mathrm{g}\left[{ }^{14} \mathrm{C}\right] \mathrm{PC}$ were added to FPF. The possible effects of the added protein on FPF osmolality and hydrostatic pressure were discussed in the accompanying report (25), where it was shown that the effect on liquid dynamics during a 90 -min period of observation would be negligible. The very small amount of added $\left[{ }^{14} \mathrm{C}\right] \mathrm{PC}$ is consonant with its role as a phospholipid tag in these experiments. The significance of the $\left[{ }^{14} \mathrm{C}\right] \mathrm{PC}$-protein complex is discussed in the final section of the present report.

We found the $\left[{ }^{14} \mathrm{C}\right] \mathrm{PC}$ to be over $98 \%$ pure by thin layer chromatography using methods described below. In addition, aliquots of $\left[{ }^{14} \mathrm{C}\right] \mathrm{PC}$ were methylated and the fatty acid esters were quantified by gas-liquid chromatography by methods described previously (24). The percentages of the fatty acid residues of $\left[{ }^{14} \mathrm{C}\right] \mathrm{PC}$ were as follows: $\mathrm{C}_{8: 0} 18.4 \% ; \mathrm{C}_{14: 0}$ $25.0 \%, \mathrm{C}_{16: 0} 52.5 \% ; \mathrm{C}_{16: 1} 3.7 \%$; and $\mathrm{C}_{16: 2}$ or $\mathrm{C}_{17} 0.4 \%$.

The injectate was mixed with FPF by moving $20 \mathrm{ml}$ between a syringe and the lung at the rate of $20 \mathrm{cycles} / \mathrm{min}$ (25). Samples of FPF, $1.0-3.5 \mathrm{ml}$, and of blood, $1.0 \mathrm{ml}$, were obtained at 15,30 , and 45 min (fetus 3). Additional samples were taken at 3,60 , and 90 min (fetuses 1 and 2 ) and at 3,60, and $75 \mathrm{~min}$ (fetus 4 ).

\section{STABILITY OF ISOTOPES}

The stability of RISA in FPF was verified as described previously (25). The stability of protein-complexed $\left[{ }^{14} \mathrm{C}\right] \mathrm{PC}$ in FPF was verified as follows. Aliquots of the original injectate and of the 3- and 90-min FPF samples were separated by polyacrylamide disc gel electrophoresis, $7.0 \%$ gel (24). The gels revealed several protein bands (Fig. 1). The albumin band, the proteins of the separation gel (excluding albumin), and the spacer gel were isolated and prepared for ${ }^{14} \mathrm{C}$ radioisotope survey.

\section{CALCULATION OF FPF VOLUME, VOLUME CHANGE, AND FATE OF PC}

The FPF volume at the time of injection (Ve) was calculated from the RISA dilution curve by extrapolation to zero time (25). The rate of change of FPF volume (Vs) was taken as the slope, $\mathrm{dV} / \mathrm{dt}$, of the plot. FPF volume at each sampling period (Vs) was determined as

$$
V_{s}=\frac{I_{A}-S_{A}}{C_{A}}
$$

where $I_{A}=$ amount (counts per minute) of RISA injected initially; $S_{A}=$ amount (counts per minute) of RISA removed in previous sample(s); and $\mathrm{C}_{\mathrm{A}}=$ concentration of RISA (counts per minute per milliliter) in the sample.

The lipids were extracted from each FPF sample in $\mathrm{CHCl}_{3}: \mathrm{CH}_{3} \mathrm{OH} 2: 1$ and ${ }^{14} \mathrm{C}$ activity of the total lipid extract was determined. Lipids were then separated by silica gel thin layer chromatography (TLC) in two solvent systems: $\mathrm{CHCl}_{3}: \mathrm{CH}_{3} \mathrm{OH}$ :conc $\mathrm{NH}_{4} \mathrm{OH}: \mathrm{H}_{2} \mathrm{O}(70: 25: 1: 4)$ followed by hexane-ether-acetic acid $(80: 25: 1)$. Lipids were identified by standards run in parallel (32). Spots were developed in $I_{2}$ vapor and individual lipids were scraped from the TLC plates and surveyed for ${ }^{14} \mathrm{C}$ activity. Blood samples were centrifuged after collection; the serum lipids were extracted and separated by TLC and aliquots were prepared for radioisotope survey as described for FPF.

Duplicate aliquots of the total lipid extracts were dried and mixed with Omnifluor (33):Bio-Solv (34):toluene (1:50:250, $\mathrm{w} / \mathrm{v} / \mathrm{v})$ in counting vials. The scraped spots from TLC plates were mixed with the same scintillation medium. All vials were counted in an Intertechnique scintillation counter (35). Total lipid extracts from the polyacrylamide disc gels were assayed in the same manner after dissolving the gel in Soluene (36). Interference from RISA was not expected and this was verified by surveying the lipids for $\gamma$ activity; there was none.

The fractional amount of ${ }^{14} \mathrm{C}$ activity in lipids from TLC was determined and the concentration was obtained by multiplying (fractional ${ }^{14} \mathrm{C}$ activity) by (total lipid ${ }^{14} \mathrm{C}$ activity) per milliliter of sample. The activity in FPF was taken as the product (disintegrations per minute per milliliter) $x$ (Vs). For those samples of FPF that were obtained before homogeneous distribution of RISA (e.g., at $3 \mathrm{~min}$ ), FPF activity was determined by assuming that the distribution of both RISA and $\left[{ }^{14} \mathrm{C}\right]$ PC-protein was essentially the same.

\section{IN VITRO EXPERIMENTS}

The FPF was taken from a full term fetus which had not been used in prior experimentation. The FPF was divided into aliquots of $2.0 \mathrm{ml}$ to which $0.125 \mu \mathrm{Ci}\left[{ }^{14} \mathrm{C}\right] \mathrm{PC}(31)$ and Tris buffer were added. Quadruplicate tubes were brought to $\mathrm{pH} 6$, 7 , and 8 , respectively, and incubated at $37^{\circ}$ for $90 \mathrm{~min}$. Samples were taken at 3 and $90 \mathrm{~min}$ and extracted in $\mathrm{CHCl}_{3}: \mathrm{CH}_{3} \mathrm{OH}$, to which was added $98 \mu \mathrm{g}$ PC from a standard mixture (32) of PC, phosphatidylethanolamine, lysolecithin, and cholesterol, and then separated on TLC. The standard mixture was used to facilitate identification and recovery of lipids from the TLC plates. Aliquots of total lipid extract and of individual lipids from TLC were surveyed for radioactivity as described.

\section{RESULTS}

The distribution of ${ }^{14} \mathrm{C}$ within the separation and spacer gels after disc electrophoresis of the original injectate (RISA + $\left[{ }^{14} \mathrm{C}\right]$ PC-protein) was $45 \%$ in the albumin band, $36 \%$ in the other proteins of the separation gel, and $19 \%$ in the spacer gel. The distribution of the ${ }^{14} \mathrm{C}$ that remained in FPF after 3 and 90 min was $45 \%$ in albumin, $47 \%$ in other proteins of the 
separation gel, and $8 \%$ in the spacer gel. The electrophoretic migration of proteins is shown in Figure 1.

The decrease in FPF ${ }^{14} \mathrm{C}$-PC radioactivity with time is presented in Figure 2 as is the decrease of ${ }^{14} \mathrm{C}$ activity in the total lipids of FPF. Two slopes are apparent from inspection of the mean disintegrations per minute-time plot (Fig. 2): The first, 3-30 min after $\left[{ }^{14} \mathrm{C}\right] \mathrm{PC}$ was introduced in to FPF, gives a half-time for $\left[{ }^{14} \mathrm{C}\right] \mathrm{PC}$ of approximately $15 \mathrm{~min}$; and the second, 30-90 min after the introduction of $\left[{ }^{14} \mathrm{C}\right] \mathrm{PC}$, gives a half-time of approximately $57 \mathrm{~min}$. Fetus 3 differed from the others in that Vs was about 3-4 times more rapid (Fig. 2) and the slope, ddpm/dt, at 15-45 min gave a half-time for $\left[{ }^{14} \mathrm{C}\right] \mathrm{PC}$ of approximately $30 \mathrm{~min}$.

Of the total radioactivity in the lipids of FPF about $90 \%$ $(80 \%-95 \%)$ was recovered in PC, about $7 \%$ was in phospholipids other than PC (including lyso-PC, sphingomyelin, and phosphatidylethanolamine), about $1.0 \%$ was recovered in cholesterol, cholesteryl esters, tri- and diglycerides, and about $3 \%$ in free fatty acids (Table 1 ).

The results of the in vitro experiments are given in Figure 3. After 90 min incubation at $37^{\circ}, 92-95 \%$ of the ${ }^{14} \mathrm{C}$ activity at $3 \mathrm{~min}$ was still in $\mathrm{PC}, 5 \%-8 \%$ of the activity was recovered in lyso-PC and fatty acids, and total ${ }^{14} \mathrm{C}$ activity was unchanged. The decrease in $\left[{ }^{14} \mathrm{C}\right] \mathrm{PC}$ activity was slightly greater as $\mathrm{pH}$ was increased above 6 . Comparison with the fate of $\left[{ }^{14} \mathrm{C}\right] \mathrm{PC}$ in vivo (Fig. 3) is striking: after 75-90 min in FPF in vivo, only $11 \%-15 \%$ of the $\left[{ }^{14} \mathrm{C}\right] \mathrm{PC}$ that was present at 3 min remains. Thus, loss of $\left[{ }^{14} \mathrm{C}\right] \mathrm{PC}$ is roughly 7 times greater in vivo than it is in vitro.

The recovery of ${ }^{14} \mathrm{C}$ activity in serum and its distribution among serum lipids is summarized in Figure 4 . The radioisotope was present in each AAo and RA sample including those taken 3 min after $\left[{ }^{14} \mathrm{C}\right] \mathrm{PC}$ had been injected into FPF. Fatty acids (FA) accounted for most of the ${ }^{14} \mathrm{C}$ activity of arterial (AAo) serum: thus, $\left[{ }^{14} \mathrm{C}\right] \mathrm{FA}$ made up $71-91 \%($ mean $=80 \%)$ of the total activity of the lipids. Conversely, the proportional content of $\left[{ }^{14} \mathrm{C}\right] \mathrm{FA}$ in RA serum was generally lower and showed greater variation, $15-88 \%($ mean $=46 \%)$, than that of AAo serum. In 15 of 17 paired samples there was an AAo to $\mathrm{RA}$ gradient for $\left[{ }^{14} \mathrm{C}\right] \mathrm{FA}$; in two paired samples $\left[{ }^{14} \mathrm{C}\right] \mathrm{FA}$ activity was slightly higher in RA serum. The distribution of ${ }^{14} \mathrm{C}$ within other lipids of AAo serum was generally greater in phospholipids (including PC, phosphatidylethanolamine, sphingomyelin, and lyso-PC) than in neutral lipids (including cholesterol, cholesteryl esters, and tri- and diglycerides). The same was true for RA serum except in the case of Fetus 1 where most of the isotope was present in neutral lipids.

\section{DISCUSSION}

Pulmonary phospholipids, predominantly disaturated PC, are synthesized in the lung and secreted into the alveolar space $(8,27,28)$, where they help form and maintain the alveolar lining layer of the air-breathing mammal. The remarkable rapidity of this process was demonstrated by the observation of Darrah and Hedley-Whyte (8) that $43 \%$ of the radioactivity in the lung was present in PC $1 \mathrm{~min}$ after radiolabeled palmitate was injected into the circulation. We have shown that serum $\left[{ }^{14} \mathrm{C}\right]$ palmitate precursor is also rapidly metabolized in the lamb fetus and that the label appears in phospholipids of FPF within 15 min after intravenous administration (19). For the air-lung the biologic half-time of pulmonary $\mathrm{PC}$ is $12-14 \mathrm{hr}(27,28)$, and the estimated half-time of PC of the alveolar lining layer (alveolar PC) is 17.5 hr (27). Analogous data, however, are not available for the fetus and FPF, and little is known about the degradation and disposal of alveolar PC in general.

We feel that FPF is an excellent source for the study of alveolar PC and, in addition, that extrapolations may be made to the alveolar lining layer of the air-lung for several reasons:

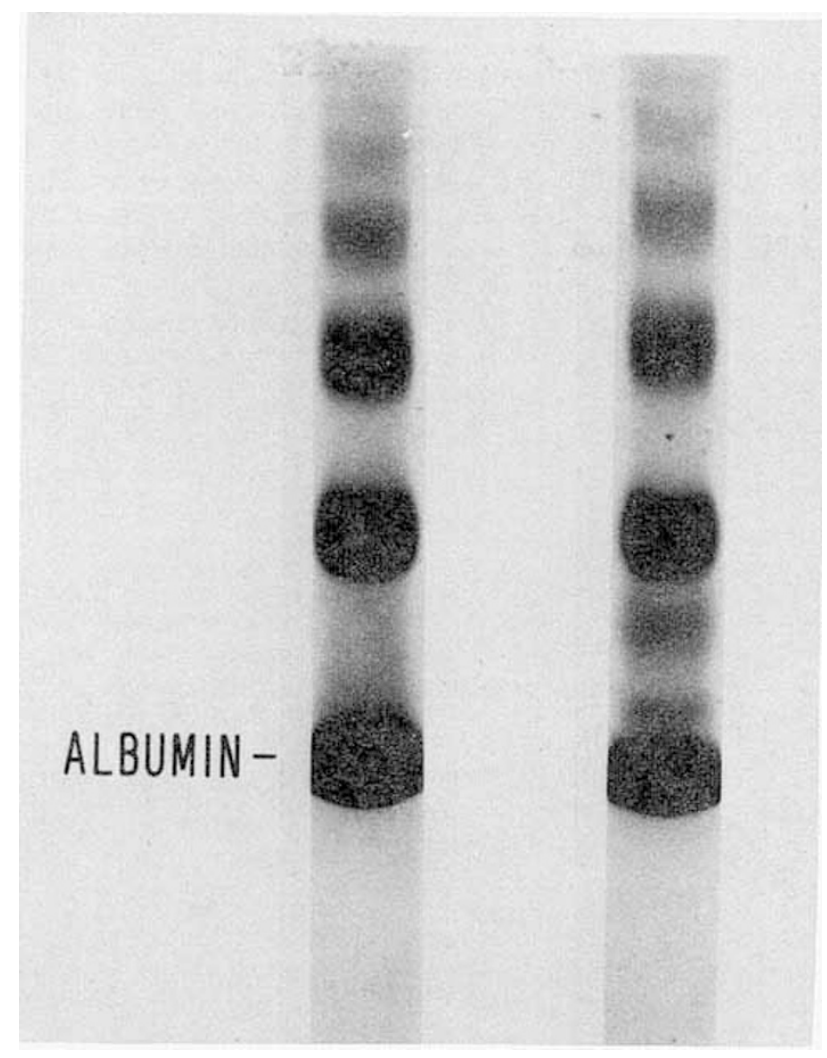

Fig. 1. Polyacrylamide gel electrophoresis. Left: the proteins to which ${ }^{14} \mathrm{C}$-labeled phosphatidylcholine was complexed in injectate (see Reference 31). Albumin contained $45 \%$ of the ${ }^{14} \mathrm{C}$ activity; the other proteins contained $36 \% ; 19 \%$ was in the spacer gel (not shown). Right: fetal pulmonary fluid proteins 90 min after administration of injectate in vivo. Protein distribution is similar to that of injectate, except for two additional bands in the postalbumin region. The ${ }^{14} \mathrm{C}$ distribution was $45 \%$ in albumin, $47 \%$ in other proteins, and $8 \%$ in spacer gel (not shown). Interestingly, protein distribution in crude FPF (i.e., without injectate) resembles that shown on the right (see Reference 19).

FPF contains the same surface-active phospholipids that are found in pulmonary washings which presumably sample the alveolar surface; these lipids are products of alveolar epithelial cell synthesis and secretion; and they presumably help to establish the alveolar lining layer of the air-lung at birth $(2,11$, $20,21)$. The FPF offers the advantage of direct sampling from the natural state, whereas sampling of the alveolar lining layer introduces a number of problems including contamination from other pulmonary sources $(22,24)$.

\section{PC-PROTEIN COMPLEX}

As expected, both the "albumin" (31) that was used to complex $\left[{ }^{14} \mathrm{C}\right] \mathrm{PC}$ and the FPF contained other, slower-moving proteins (References 19, 24, and Fig. 1) with which $47 \%$ of the $\left[{ }^{14} \mathrm{C}\right] \mathrm{PC}$ was associated after electrophoresis of FPF. In addition, $45 \%$ of the $\left[{ }^{14} \mathrm{C}\right] \mathrm{PC}$ of FPF migrated with albumin in the disc gels. Thus we may conclude that over $90 \%$ of the $\left[{ }^{14} \mathrm{C}\right] \mathrm{PC}$ tag was complexed with protein in the FPF of the present studies.

Migration of $\left[{ }^{14} \mathrm{C}\right] \mathrm{PC}$ with protein into the disc gels is of interest, since previous studies of the air-lung of adult animals showed that more than $90 \%$ of the phospholipids in pulmonary washings, derived presumably from the alveolar lining layer as the primary source, do not enter the polyacrylamide gel $(23,24)$. Thus the PC-protein complexes that were produced in the laboratory (i.e., in the injectate, where the protein to $\mathrm{PC}$ ratio and protein concentration were much higher than in pulmonary washings (24)) are more stable 

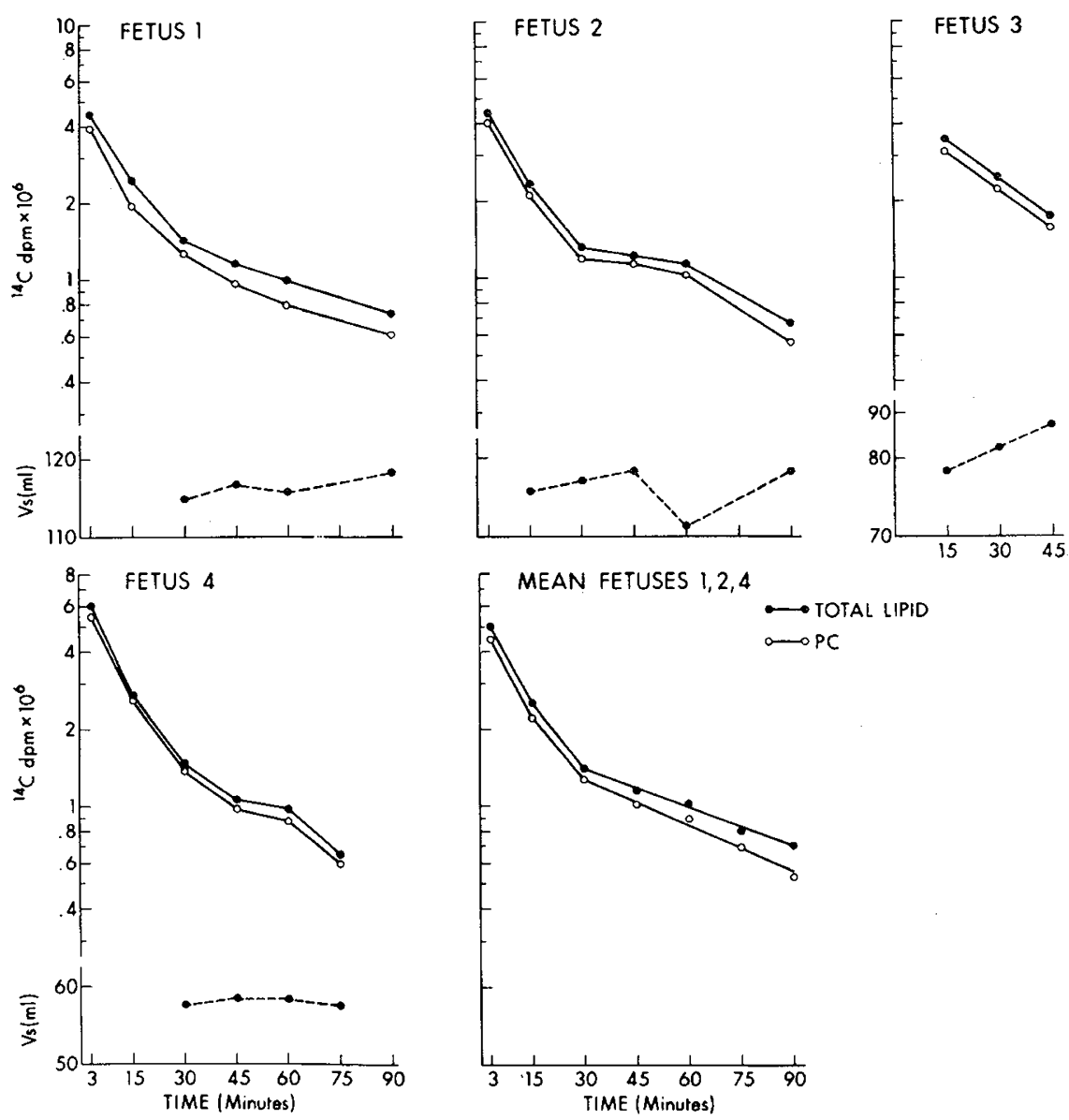

Fig. $2 .{ }^{14} \mathrm{C}$ activity in total lipids $(\bullet)$ and phosphatidylcholine $(P C)(0)$ at various times after mixing $\left[{ }^{14} \mathrm{C}\right]$ PC-protein in fetal pulmonary fluid (FPF) in vivo. - - : FPF volume (Vs).

than those derived from pulmonary lavage, in so far as they persist in the electrophoretic field and during migration through the gel. In addition, although the number of complexes may be increased, they are otherwise unchanged when the injectate is mixed with FPF.

In the accompanying paper (25), we indicated that RISA diffuses rapidly and homogeneously within FPF and that there is no direct transfer of RISA out of the FPF compartment during the period of study. We also indicated that the primary barrier to direct transfer of RISA out of FPF was the lumenal surface of epithelial cells (25). Therefore, if the $\left[{ }^{14} \mathrm{C}\right] \mathrm{PC}$-protein complexes of the present study had retained diffusion and permeability characteristics similar to those of RISA in FPF, we may assume that $\left[{ }^{14} \mathrm{C}\right] \mathrm{PC}$ distribution in FPF paralleled RISA distribution and also that the alveolar epithelial cells were the primary barrier to direct transfer of $\left[{ }^{14} \mathrm{C}\right] \mathrm{PC}$ out of the alveoli. The former assumption was made in our calculations of $\left[{ }^{14} \mathrm{C}\right] \mathrm{PC}$ content in FPF. The latter assumption supports the idea that $\left[{ }^{14} \mathrm{C}\right] \mathrm{PC}$ does not leave the FPF compartment directly and that clearance of $\left[{ }^{14} \mathrm{C}\right] \mathrm{PC}$ from FPF may begin at the epithelial surfaces of the alveoli, as discussed in the following section.

\section{FATE OF PC-PROTEIN IN FPF}

Since our assay in these experiments was the ${ }^{14} \mathrm{C}$ activity in lipids of FPF that was sampled from the trachea, our comments will be restricted to the clearance of $\left[{ }^{14} \mathrm{C}\right] \mathrm{PC}$ from the bulk liquid phase of FPF. From this perspective it is apparent that $\left[{ }^{14} \mathrm{C}\right] \mathrm{PC}$ is cleared rapidly. The slope, $\left[{ }^{14} \mathrm{C}\right] \mathrm{PC}$ $\mathrm{ddpm} / \mathrm{dt}$, gives a half-time of about $15 \mathrm{~min}$ between 3 and 30 $\mathrm{min}$, and a half-time of about $57 \mathrm{~min}$ between 30 and $90 \mathrm{~min}$. These times are extremely rapid when compared with the biologic half-time of $17.5 \mathrm{hr}$ for "alveolar" PC (27). The latter includes the process of transfer of palmitate precursor from blood to epithelial cell, incorporation of palmitate into $\mathrm{PC}$ during biosynthesis, secretion of $\mathrm{PC}$ into the alveolar space, and degradation and removal of $\mathrm{PC}$ from the alveolus. If these studies of pulmonary PC of the air-lung may be compared with our findings on FPF-PC, it appears that clearance of extracellular PC in the bulk liquid phase of FPF is a short interval in the total life of the molecule.

From our studies of $\dot{V}$ s and Ve (25), it is apparent that only about $5 \%$ of total FPF can leave the lung per hour without a net depletion of FPF volume. This relatively slow flow, coupled with rapid clearance of PC in situ, suggests that pulmonary PC can make only a small contribution to the PC content of amniotic fluid. The additional observations that PC is degraded rapidly in amniotic fluid itself (18), that other, nonpulmonary, sources account for phospholipids in amniotic fluid (5), and that it is quite problematic that FPF is expectorated by the lamb into amniotic fluid in the first place (1), indicate that further study is needed before categorical acceptance of the lung as a major or exclusive source of amniotic fluid phospholipids $(4,14)$.

There are several possibilities regarding the site at which PC of bulk FPF is cleared: the first is FPF itself. Our in vitro experiments (Fig. 3) indicate that degradative processes within FPF could account for less than $10 \%$ of the total breakdown of $\left[{ }^{14} \mathrm{C}\right] \mathrm{PC}$. Since the ${ }^{14} \mathrm{C}$ is recovered in fatty acids and lyso-PC of FPF, the possibility presents itself that phospholipase(s) may be active within FPF. The presence of phospholipase $\mathrm{A}$ in pulmonary tissue of adult rats has been demonstrated (13), but to our knowledge the possibility of extracellular pulmonary deacylation has not been reported heretofore. As noted above, degradation (not further specified) of PC also takes place rapidly in amniotic fluid (18), but 
Table 1. Distribution of ${ }^{14} \mathrm{C}$ activity in fetal pulmonary fluid ${ }^{1}$

\begin{tabular}{|c|c|c|c|c|c|}
\hline Fetus & $\begin{array}{l}\text { Total lipid }{ }^{14} \mathrm{C} \\
\mathrm{dpm} \times 10^{6}\end{array}$ & $\begin{array}{l}\%^{14} \mathrm{C} \\
\text { in PC }\end{array}$ & $\begin{array}{l}\%^{14} \mathrm{C} \\
\text { in PL }\end{array}$ & $\begin{array}{l}\%^{14} \mathrm{C} \\
\text { in FA }\end{array}$ & $\begin{array}{l}\%^{14} \mathrm{C} \\
\text { in NL }\end{array}$ \\
\hline \multicolumn{6}{|l|}{$3 \mathrm{~min}$} \\
\hline 1 & 4.6 & 86 & 10 & 2.5 & 1.0 \\
\hline 2 & 4.4 & 92 & 5 & 2.0 & 0.5 \\
\hline 3 & & & & & \\
\hline 4. & 6.1 & 91 & 4 & 1.5 & 1.0 \\
\hline Mean & 5.0 & 89.7 & 6.3 & 2.0 & 0.8 \\
\hline \multicolumn{6}{|l|}{$15 \mathrm{~min}$} \\
\hline 1 & 2.5 & 80 & 9 & 7.0 & 1.5 \\
\hline 2 & 2.4 & 90 & 6 & 2.5 & 1.0 \\
\hline 3 & 3.5 & 89 & 8 & 0.5 & 1.0 \\
\hline 4 & 2.7 & 95 & 3 & 1.5 & 0.1 \\
\hline Mean & 2.8 & 88.5 & 6.5 & 2.9 & 0.9 \\
\hline \multicolumn{6}{|l|}{$30 \mathrm{~min}$} \\
\hline 1 & 1.5 & 88 & 5 & 6.0 & 0.5 \\
\hline 2 & 1.3 & 90 & 5 & 3.0 & 0.5 \\
\hline 3 & 2.5 & 89 & 8 & 1.0 & 1.5 \\
\hline 4 & 1.5 & 94 & 4 & 1.5 & 0.1 \\
\hline Mean & 1.7 & 90.3 & 5.5 & 2.9 & 0.7 \\
\hline \multicolumn{6}{|l|}{$45 \mathrm{~min}$} \\
\hline 1 & 1.2 & 83 & 9 & 6.0 & 1.0 \\
\hline 2 & 1.2 & 92 & 3 & 3.5 & 0.5 \\
\hline 3 & 1.8 & 88 & 7 & 2.0 & 0.5 \\
\hline 4 & 1.1 & 92 & 4 & 3.0 & 0.2 \\
\hline Mean & 1.3 & 88.8 & 5.8 & 3.6 & 0.6 \\
\hline \multicolumn{6}{|l|}{$60 \mathrm{~min}$} \\
\hline 1 & 1.0 & 80 & 13 & 6.0 & 1.0 \\
\hline 2 & 1.15 & 90 & 5 & 3.0 & 1.0 \\
\hline \multicolumn{6}{|l|}{3} \\
\hline 4 & 0.95 & 93 & 5 & 1.5 & 0.2 \\
\hline Mean & 1.1 & 87.7 & 7.7 & 3.5 & 0.7 \\
\hline \multicolumn{6}{|l|}{$90 \mathrm{~min}$} \\
\hline 1 & 0.7 & 82 & 10 & 6.0 & 2.0 \\
\hline 2 & 0.7 & 84 & 11 & 4.5 & 0.5 \\
\hline \multicolumn{6}{|l|}{3} \\
\hline $4(75 \mathrm{~min})$ & 0.65 & 93 & 5 & 3.0 & 0.2 \\
\hline Mean & 0.7 & 86.3 & 8.7 & 4.5 & 0.9 \\
\hline
\end{tabular}

${ }^{1} \mathrm{PC}$ : phosphatidylcholine; PL: phospholipids (excluding PC); FA: fatty acids; NL: neutral lipids.

the half-time seems to be approximately twice as long as that of FPF. A second possible pathway for the clearance of PC is through incorporation into pulmonary macrophages. This has been suggested as a mechanism for removal of components of the surfactant system in the alveolar lining layer of the air-lung $(20,29)$. Although the mechanism may be valid ex utero, it is probably insignificant in the fetus because of the sparcity of pulmonary macrophages during gestation (16). However, since we made no attempt to recover macrophages in our experiments we cannot speculate further. A third possibility presents itself from the observation that over $90 \%$ of the $\left[{ }^{14} \mathrm{C}\right] \mathrm{PC}$ was complexed with albumin and other proteins in FPF (Fig. 1) and that proteins probably do not permeate the alveolar epithelial barrier at its lumenal surface $(15,25,26)$. Thus, direct transfer of protein-bound PC out of FPF is not anticipated. Therefore, it is reasonable to suggest that rapid clearance (including degradation) of $\left[{ }^{14} \mathrm{C}\right] \mathrm{PC}$ from $\mathrm{FPF}$ in vivo may begin at the lumenal surface of the alveolar epithelial cell, possibly after adsorption at the surface. In fact, it is

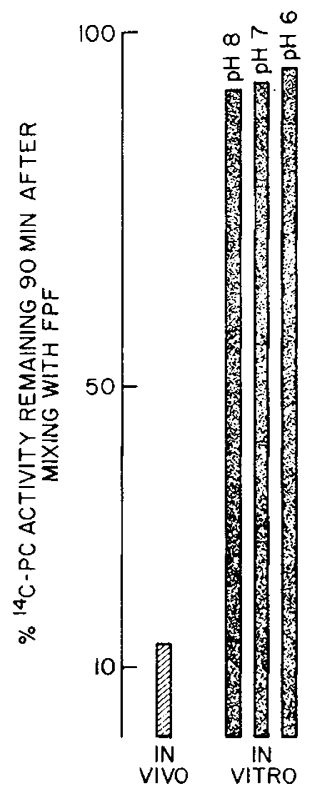

Fig. 3. Percentage of labeled phosphatidylcholine $\left({ }^{14} C\right.$-PC $)$ activity remaining at $90 \mathrm{~min}$ compared with activity $(100 \%)$ at $3 \mathrm{~min}$ in fetal pulmonary fluid $(F P F)$ in vitro $(\mathrm{pH} 6,7$, and 8$)$ and in vivo.
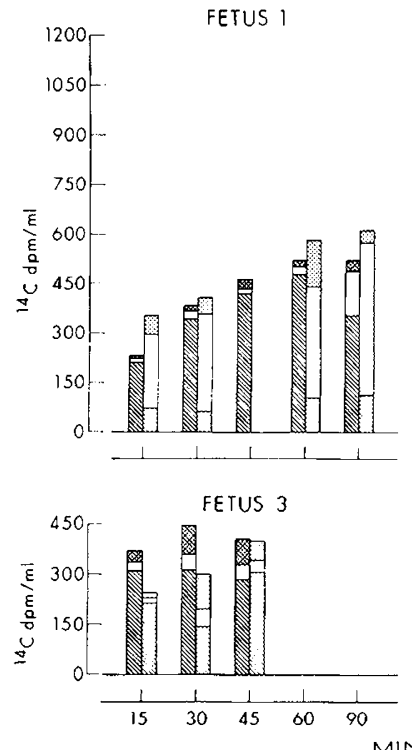

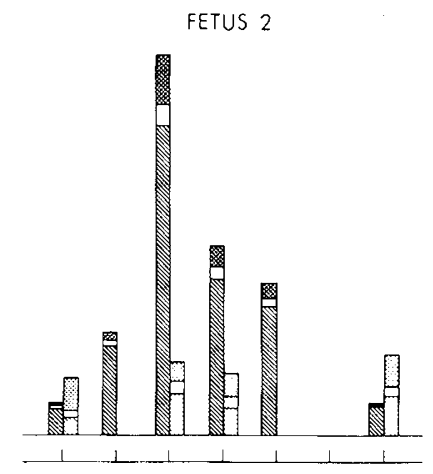

FETUS 4

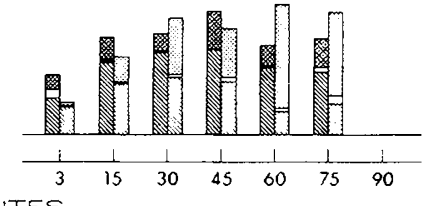

Fig. 4. Distribution of ${ }^{14} \mathrm{C}$ activity in serum lipids at various times after introducing ${ }^{14} \mathrm{C}$-labeled phosphatidylcholine-protein into fetal pulmonary fluid. Paired bars represent ascending aortic (AAo) serum (left) and right atrial serum (right). Single bars represent AAo serum. Hatched areas, fatty acids; clear areas, neutral lipids; cross-hatched areas, phospholipids.

known that reactions involving lipid substrates often proceed at significant rates only when a definite lipid-water interface is formed (10), e.g., FPF-PC at the plasma membrane, rather than in an aqueous environment where the substrate may be present as small loose aggregations of a few molecules only, e.g., FPF-PC in FPF. If initial clearance of protein-complexed PC does take place at the epithelial surface, we may speculate that the products of subsequent degradation, including fatty acids, could gain access to the cell or interstitium or be transferred directly to the circulation $(3,12)$. Our observations that ${ }^{14} \mathrm{C}$-labeled fatty acids predominate in arterial blood and that there is a marked increase from venous to arterial blood (Fig. 4) are in accord with this scheme (Fig. 5). The identification of phospholipase $\mathrm{A}_{1}$ activity in plasma membranes of rat liver cells by Newkirk and Waite (17) lends additional support by analogy. 


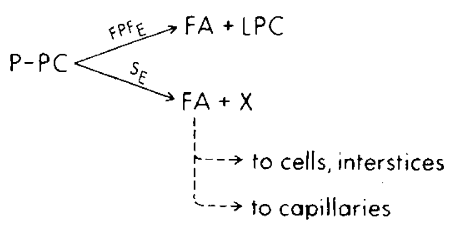

Fig. 5. Schematic (hypothetical) indicating two proposed routes of phosphatidylcholine $(P C)$ degradation in fetal pulmonary fluid $(F P F)$. $P$-PC: protein-complexed PC in FPF; $F P F_{E}$ : proposed phospholipase activity in FPF; $S_{E}$ : proposed enzyme (phospholipase?) activity at the plasma membrane; $F A$ : fatty acids; $L P C$ : lyso $\mathrm{PC} ; X$ : products (general) of $\mathrm{PC}$ degradation.

\section{${ }^{14} \mathrm{C}$ IN CIRCULATION}

Over $70 \%$ of the ${ }^{14} \mathrm{C}$ activity in AAo serum was present in fatty acids (FA) and the rest was distributed among the phospholipids and neutral lipids (Table 1). There was a sharp increase of $\left[{ }^{14} \mathrm{C}\right] \mathrm{FA}$ activity from venous (RA) to arterial (AAo) blood (Fig. 4), which indicates uptake of FA from the lung and delivery of FA to tissues served by the systemic circulation. Uptake of FA, including palmitic acid, from the lung to the circulation of adult humans has been documented (7). It is now demonstrated that FPF-PC is one source of FA and that transfer takes place even in the relatively ischemic lung of the fetus. Thus we may establish the fetal lung as a source as well as a consumer (19) of circulating FA, specifically with regard to PC metabolism: PC (pulmonary) $\rightleftharpoons$ FA (circulating). The recorded systemic arteriovenous difference for $\left[{ }^{14} \mathrm{C}\right] \mathrm{FA}$ is probably lower than the actual pulmonary venoarterial difference because AAo blood contains some venous admixture primarily from the right to left shunt at the atrial level (9).

Of further interest are the arteriovenous differences of other ${ }^{14} \mathrm{C}$ lipids, which indicate that phospholipids and neutral lipids may enter the lung from the circulation and vice versa. Condorelli et al. (7) reported that phospholipids and cholesteryl esters are removed from blood as it passes through the lung of the adult human, but that net transfer of triglycerides and cholesterol is variable. From the present data we cannot be more specific concerning neutral lipids since they were not examined individually. Arteriovenous differences that were obtained for PC do not allow conclusions regarding flux between blood and lung. However, we have shown in other studies (6) that circulating PC does enter the lung of the fetal rabbit directly.

\section{SUMMARY}

The disappearance of protein-complexed $\left[{ }^{14} \mathrm{C}\right] \mathrm{PC}$ from FPF in vivo was quantitated using the RISA dilution method (25) to establish FPF volume. $\left[{ }^{14} \mathrm{C}\right] \mathrm{PC}$ was cleared rapidly from FPF with an estimated half-time of $15-57 \mathrm{~min}$. The studies indicate that FPF $\left[{ }^{14} \mathrm{C}\right] \mathrm{PC}$ may be metabolized to lyso-PC and fatty acid within FPF itself. It is also suggested that PC-degradative enzymes are active at the surface of the alveolar epithelial cells and that this activity may account for most of the clearance of $\left[{ }^{14} \mathrm{C}\right] \mathrm{PC}$ from FPF. Fatty acids derived from FPF-PC enter the pulmonary circulation, thus establishing a pulmonary arteriovenous fatty acid gradient.

\section{REFERENCES AND NOTES}

1. Adams, F. H., Desilets, D. T., and Towers, B.: Control of flow of fetal lung fluid at the laryngeal outlet. Resp. Physiol., 2: 302 (1967).

2. Adams, F. H., Fujiwara, T., and Rowshan, G.: The nature and origin of the fluid in the fetal lamb lung. J. Pediat., 63: 881 (1963).

3. Chinard, F. P.: The permeability characteristics of the pulmonary blood-gas barrier. In: C. G. Caro: Advances in Respiratory Physiology (The Williams \& Wilkins Co., Baltimore, 1966).

4. Clements, J. A., Platzker, A. C. G., Tierney, D. F., Hobel, C. I., Creasy, R. K., Margolis, A. J., Thibeault, D. W., Tooley, W. H., and $\mathrm{Oh}, \mathrm{W} .:$ Assessment of the risk of the respiratory-distress syndrome by a rapid test for surfactant in amniotic fluid. $N$. Engl. J. Med., 286: 1077 (1972).

5. Condorelli, S., Cosmi, E. V., and Scarpelli, E. M.: Extrapulmonary source of amniotic fluid phospholipids. Amer. J. Obstet. Gynecol., 118: 842 (1974).

6. Condorelli, S.. Cosmi, E. V.. and Scarpelli, E. M.: Distribution and fate of plasma lecithin-U- ${ }^{14} \mathrm{C}$ in pregnant rabbit (Abstract). Clin. Res., 21: 984 (1974).

7. Condorelli, S., Lombardi, D., Gusmano, R., and Pisano, L.: Pulmonary A-V differences of lipids and free fatty acids in relation to fasting and to high fat meals. Clin. Chim. Acta, 38 : 141 (1972).

8. Darrah, H. K., and Hedley-Whyte, J.: Rapid incorporation of palmitate into lung: site and metabolic fate. J. Appl. Physiol., 34: 205 (1973).

9. Dawes, G. S.: Foetal and Neonatal Physiology, p. 92 (Year Book Medical Publishers, Chicago, 1968).

10. Dawson, R. M. C.: Specificity of enzymes involved in the metabolism of phospholipids. In: G. B. Ansell, R. M. C. Dawson, and J. N. Hawthorne: Form and Function of Phospholipids (Elsevier Scientific Publishing Co., Amsterdam, 1973).

11. Enhörning, G., Grossman, G., and Robertson, B.: Tracheal deposition of surfactant before the first breath. Amer. Rev. Resp. Dis., 107: 921 (1973).

12. Felts, J. M.: Carbohydrate and lipid metabolism of lung tissue in vitro. Med. Thorac., 22: 89 (1965).

13. Gallai-Hatchard, J. J., and Thompson, R. H. S.: Phospholipase-A activity of mammalian tissues. Biochim. Biophys. Acta, 98: 128 (1965).

14. Gluck, L., Kulovich, M. V., Borer, R. C., Jr., Brenner, P. H., Anderson, G. G., and Spellacy, W. N.: Diagnosis of the respiratory distress syndrome by amniocentesis. Amer. J. Obstet. Gynecol., 109: 440 (1971).

15. Gonzalez-Crussi, F., and Boston, R. W.: The absorptive function of the neonatal lung. Lab. Invest., 26: 114 (1972).

16. Kikkawa, Y.: Personal communication.

17. Newkirk, J. D., and Waite, M.: Identification of phospholipase $A_{1}$ in plasma membranes of rat liver. Biochim. Biophys. Acta, 225: 224 (1971).

18. Reynolds, W. A., Pitkin, R. M., and Filer, L. J., Jr.: Phospholipid synthesis by the monkey fetus. Med. Primatol., Part III, p. 368 (Proceedings of the Third Conference on Experimental Medical Surgery on Primates, Lyon, 1972).

19. Scarpelli, E. M.: The lung, tracheal fluid, and lipid metabolism of the fetus. Pediatrics, 40: 941 (1967).

20. Scarpelli, E. M.: The Surfactant System of the Lung (Lea \& Febiger, Philadelphia, 1968).

21. Scarpelli, E. M., Agasso, E. J., and Kikkawa, Y.: Demonstration of the significance of pulmonary surfactants at birth. Resp. Physiol., 12: 110 (1971).

2. Scarpelli, E. M., Clutario, B. C. and Taylor, F. A.: Preliminary identification of the lung surfactant system. J. Appl. Physiol., 23: 880 (1967).

23. Scarpelli, E. M., Chang, S. J., and Colacicco, G.: A search for the surface-active pulmonary lipoprotein. Amer. Rev. Resp. Dis., 102: 285 (1970).

24. Scarpelli, E. M., Colacicco, G., and Chang, S. J.: Significance of methods for isolation and characterization of pulmonary surfactants. Resp. Physiol., 12: 179 (1971).

25. Scarpelli, E. M., Condorelli, S., and Cosmi, E. V.: Lamb fetal pulmonary fluid. I. Validation and significance of method for determination of volume and volume change. Pediat. Res., 9: 190 (1975).

26. Schneeberger-Keely, E. M., and Karnovsky, M. J.: The influence of intravascular fluid volume on the permeability of newborn and adult mouse lungs to ultrastructural protein tracers. J. Cell Biol., 49: 319 (1971).

27. Thomas, T., Jr., and Rhoades, R. A.: Incorporation of palmitate-1-14 $\mathrm{C}$ into lung tissue and "alveolar" lecithin. Amer. J. Physiol., 219: 1535 (1970).

28. Tierney, D. F., Clements, J. A., and Trahan, H. S.: Rates of replacement of lecithins and alveolar instability in rat lungs. Amer. J. Physiol., 213: 671 (1967).

29. Weibel, E. R.: Discussion in A. V. A. de Reuck and R. Porter: Development of the Lung, pp. 170-176 (Churchill, London, 1967).

30. Air Shields, Hatboro, Pennsylvania.

31. $U-\left[{ }^{14} \mathrm{C}\right]$ Phosphatidylcholine, $1.77 \mathrm{Ci} / \mathrm{mM}$ phosphorus, New England Nuclear Corp., Boston, Mass. The $\left[{ }^{14} \mathrm{C}\right] \mathrm{PC}$ was complexed with albumin, bovine, fatty acid-poor, Mann Research Lab., New York, N. Y. This "albumin" is actually a mixture of proteins as shown in Figure 1.

32. TLC lipid standards were obtained from Applied Science Laboratories, State College, $\mathrm{Pa}$

33. New England Nuclear Corp., Boston, Mass.

34. Beckman Instruments, Inc., Fullerton, California.

35. Intertechnique Model SL 30, Intertechnique Instruments Inc., Dover, N. J. 
36. Soluene 100, Packard Instrument Co., Downer's Grove, Ill.

37. This research was supported by grants from the National Heart and Lung Institute, National Institutes of Health (HL16137); New York Heart Association grant-in-aid; and United States-Italy Cooperative Science Program (C.N.R., Rome, No. 73.00681.65). 38. Dr. E. M. Scarpelli is a recipient of a Career Development Award from the National Heart and Lung Institute of the National Institutes of Health.

39. Requests for reprints should be addressed to: E. M. Scarpelli, M.D., Department of Pediatrics, Albert Einstein College of Medicine, 1300 Morris Park Ave., Bronx, N.Y. 10461 (USA).

40. Accepted for publication January 2, 1975.
Alveolar hyaline membranes cytidine

fetus

lecithin lung neonate phosphorylcholine cytidyltransferase respiratory distress syndrome

\title{
The Enzymes of Lecithin Biosynthesis in Human Neonatal Lungs. IV. Phosphorylcholine Cytidyltransferase
}

\author{
MICHAEL L. THOM AND RICHARD D. ZACHMAN ${ }^{(37)}$ \\ Department of Pediatrics of the University of Wisconsin and The Wisconsin Perinatal Center, \\ Madison, Wisconsin, USA
}

\section{Extract}

Phosphorylcholine cytidyltransferase, the enzyme which catalyzes the transfer of phosphorylcholine to cytidine $5^{\prime}$-triphosphate to form CDP-choline, was studied for the first time in human neonatal lung. The assay of product synthesis was linear for $10-20 \mathrm{~min}$ and up to $12 \mathrm{mg}$ protein. The $\mathrm{pH}$ optimum was $6-6.5$. The $\mathrm{K}_{\mathrm{m}}$ of CTP was $2.0 \times 10^{-3} \mathrm{M}$, and the $\mathrm{K}_{\mathrm{m}}$ of phosphorylcholine was $0.25 \times 10^{-3} \mathrm{M}$. The true $\mathrm{V}_{\max }$ was $10 \mathrm{nmol}$ CDP-choline $/ \mathrm{mg}$ protein $/ 10 \mathrm{~min}$. The enzyme was stable under frozen conditions. Oxygen had no apparent affect on enzyme activity.

\section{Speculation}

In some tissues, phosphorylcholine cytidyltransferase is possibly the site for a feedback control mechanism of lecithin synthesis. Since there is a relationship between pulmonary lecithin synthesis and neonatal respiratory distress syndrome, purification and characterization of phosphorylcholine cytidyltransferase from human neonatal lung may be of significance.

Lecithin is a major component of lung alveolar surfactant $(8,20,22,24)$, and a relationship between lung surfactant and neonatal respiratory distress has been established $(1,4,9,10$, $12,15)$. Lung surfactant activity accompanies increased lecithin biosynthesis in the developing fetus of several species $(13,14,28)$, and lung extracts from infants dying of respiratory distress with alveolar hyaline membranes have abnormal surface active properties $(15,20)$. De novo lecithin synthesis in lung tissue of experimental animals occurs by at least two pathways (1) the formation of phosphorylcholine and its transfer from cytidine diphosphorylcholine (CDPcholine) to 1,2-diacyl-sn-glycerol (D- $\alpha \beta$-diglyceride) $(3,5,17$, 27), and (2) the trimethylation of ethanolamine phosphoglyceride $(7,14,19)$.
Lecithin biosynthesis in human neonatal lung is being investigated indirectly by assaying the enzyme activities of the pathways. Preliminary characterization of phosphorylcholine cytidyltransferase (EC 2.7.7.15), the enzyme responsible for the second step in the CDP-choline pathway, is reported here. Although briefly studied in the rat (26), this enzyme has not been studied previously in the human lung.

\section{EXPERIMENTAL PROCEDURE}

CTP (32) and $\mathrm{MgCl}_{2}$ (33) were used without further purification to prepare a $\mathrm{MgCTP}$ solution at $30 \mathrm{mM}$ in both magnesium and CTP. The $\mathrm{pH}$ was adjusted to 7.0 by dropwise addition of $\mathrm{NaOH}$.

Radioactive 1,2- $\left[{ }^{14} \mathrm{C}\right]$ phosphorylcholine with a specific activity of $117 \mathrm{mCi} / \mathrm{mM}$ (34) was diluted to $20 \mu \mathrm{Ci} / \mathrm{ml}$ and $1.0 \mathrm{ml}$ aliquots were stored in a freezer at $-12^{\circ}$ until use. Unlabeled phosphorylcholine $(100 \mathrm{mM})$ in phosphate buffer $(0.067 \mathrm{M}, \mathrm{pH} 7.4)$ was also frozen until the reaction solution was prepared by mixing equal volumes of unlabeled and radioactive phosphorylcholine, producing a solution $50 \mathrm{mM}$ in phosphorylcholine with a specific activity of $10 \mu \mathrm{Ci} / \mathrm{ml}$.

Lung tissue was obtained at autopsy from neonates $1-7 \mathrm{hr}$ after death and immediately frozen at $-12^{\circ}$. Just before use, a piece of lung was weighed and homogenized in a glass mortar with a motor-driven Teflon pestle in 3 volumes of phosphate buffer $(0.067 \mathrm{M}, \mathrm{pH} 7.4)$. Fresh homogenate was prepared for each assay unless otherwise indicated.

The assay used was similar to that described (6) with some modifications. The standard assay mixture contained $3-10 \mathrm{mg}$ tissue homogenate protein, Tris-succinate $(8 \mathrm{mM}, \mathrm{pH} 7.5)$, and $1,2-\left[{ }^{14} \mathrm{C}\right]$ phosphorylcholine $(1 \mu \mathrm{Ci}, 5 \mathrm{mM})$. This mixture was preincubated for $5 \mathrm{~min}$ at $37^{\triangleleft}$, then the reaction was started by the addition of MgCTP to a final concentration of $6 \mathrm{mM}$. The final volume of the incubation mixture was $1.0 \mathrm{ml}$. The samples were incubated for $10 \mathrm{~min}$ at $37^{\circ}$, and the reaction was stopped by placing the tubes in a boiling water bath for 5 